$J J M L L$

\title{
Genre Analysis of Accounts of Methodology in Arabic Educational Research Articles
}

\author{
Ahmad Tawalbeh* \\ Department of English, Irbid National University, Jordan
}

Received on: 26-3-2020

Accepted on: 15-7-2020

\begin{abstract}
Genre analysts have conducted studies on research articles (henceforth RAs) written in different languages, giving primary attention to the introduction section. The methodology has not been given similar attention although it is an essential part of empirical RAs. There are no studies, to the best of my knowledge, which have tackled accounts of methodology of Arabic RAs. This research, therefore, aims to identify the rhetorical features of accounts of methodology of Arabic educational RAs with their realisations. In pursuing this aim, 40 method sections were selected from RAs published in refereed Arabic journals in the field of Education. These were analysed based on Swales' (1990) 'move and steps' analysis approach and bottom-up processing. The linguistic features, realising the moves and steps, were analysed using the transitivity framework (Halliday 1985). The findings show that there are five moves representing the methodology: 1- sample and population of study; 2- procedures of study; 3- measure; 4variables of study; and 5- data analysis procedures. These moves are realised by a number of steps and sub-steps which are represented most often using material and relational process types. The results of this research provide insights into Arabic academic discourse. The results may also help empower beginner academic writers and enhance writing textbooks.
\end{abstract}

Keywords: Methodology, Research articles, Rhetorical structures and transitivity framework.

\section{Introduction}

The genre of research article (henceforth RA) has gained attention from genre analysts. Kanoksilapatham (2005) and Flowerdew (2013) justify this attention in terms of the role that RAs play in creating knowledge and in showing academic performance and professional progress. An RA is a means of communicating knowledge among scholars in many fields. Moreover, Swales $(1990,177)$ shows that the RA has a close relationship with other 'research-process genres' such as theses, dissertations, grant proposals, monographs, presentations and abstracts. Therefore, it is necessary to analyse the rhetorical structure of RAs.

The analysis of text structures can be performed using a top-down approach (Biber et al. 2007). One way to apply this approach is by following the move analysis that was initially developed by Swales (1981). Swales has classified the discourse units of the introduction section based on their communicative purposes, and he uses the term 'move' with its realisations 'steps' to refer to these discourse units which

๑ 2021 JJMLL Publishers/Yarmouk University. All Rights Reserved,

${ }^{*}$ Doi: https://doi.org/ 10.47012/jjmll.13.2.6

* Corresponding Author: atwalbeh2001@yahoo.com 
shape the schematic structure of a text. A 'move' can be realised in a phrase, a clause, a sentence or a paragraph and it consists of at least one proposition (Connor and Mauranen 1999).

The terms 'move' and 'step' are employed in this research following Holmes (1997), Nwogu (1997) and Swales (2004). Holmes considers a 'move' as a text segment formed by a particular communicative function. Nwogu defines a 'move' as a segment of text consisting of linguistic features and elements which can indicate the discourse content in the segment. He states that there should be a match between the linguistic features and the function of a segment to realise a 'move'. Similarly, Swales (2004, 228) defines a 'move' as 'a discoursal or rhetorical unit that performs a coherent communicative function in a written or spoken discourse'. These definitions can serve the meaning of a 'move' in this study. It can be defined as part of a text which consists of categories having specific purposes and is realised by some linguistic choices.

Swales $(1990,58)$ demonstrates the importance of communicative purposes in his definition of genre as it:

comprises a class of communicative events, the members of which share some set of communicative purposes. These purposes are recognized by the expert members of the parent discourse community, and thereby constitute the rationale for the genre.

This rationale shapes the schematic structure of the discourse.

Swales illustrates that a genre is associated with the kind of communicative event, and the communicative purpose is a criterion to identify a genre. The purpose forms the rationale which determines the content and distinguishes one genre from another. Swales' example of this is how a 'good news' letter differs from a 'bad news' letter. The rationale for the first is that communication will go on and the information conveyed is welcome, unlike the rationale of the 'bad news' letter, which indicates that the information is not welcome. However, Swales did not give attention to the importance of linguistic features in his definition as they can play a role in realising the purpose itself and hence contributing to define a genre.

One of the RA sections that has been most extensively studied is the introduction. For example, Swales (1990) focused on the rhetorical structure of the introduction section in hard and social sciences. Fakhri (2004) investigated the rhetorical patterns of the introduction section of 28 Arabic RAs from Humanities and Social Sciences. He found out that only 11 of the introductions employ the moves of 'Create a Research Space (CARS) model' created by Swales (1990). These moves are: 'Establishing a territory, Establishing a niche and Occupying the niche' (1990, 141). Fakhri observed that 11 introductions do not review previous work and another 17 include a few citations without challenging previous work. Fakhri attributed the lack of criticising previous work to cultural differences in terms of the way knowledge is conveyed and of what is considered as scholarship. These Arabic introductions focus on showing information, so they are 'knowledge-telling' type, as opposed to 'knowledgetransforming' which involves reflection and criticism. Fakhri concludes that it seems enough for the Arabic introductions to rely on knowledge-telling to prove scholarship deserving of publication. 
Genre Analysis of Accounts of Methodology in Arabic

Educational Research Articles

Moreover, there are two dissertations (AL-Qahtani 2006; Alotaibi 2013) which analysed the introduction section of English and Arabic RAs. AL-Qahtani (2006) compared and contrasted the introductions written by three groups of researchers. The first is an Arabic group educated in the Arab world, the second is an Arabic group educated in the United States and the third is a group of American native speakers. He reported that there are considerable differences between both Arabic groups in the aspect of number of sentences that shape each move of the introduction. Another difference that ALQahtani pointed to is that the second Arabic group used fewer religious sentences, deemed irrelevant, at the onset of their introduction than the first Arabic group. Finally, AL-Qahtani showed that other differences do exist between those Arabic groups and the Native American group. For example, all introductions written by the Americans include the three moves of the 'CARS model', whereas most of the introductions written by the Arabs include only two moves.

The main focus of the second dissertation (Alotaibi 2013) is the examination of the relationship between RA abstracts and introductions. Alotaibi chose 40 English and Arabic RAs from Educational Psychology and Sociology and analysed the generic organisation of the two sections, the introduction and abstract. The findings of his study confirm that these sections as well as their relation are varied across languages and disciplines. For example, there is one paragraph that represents the English abstracts, whereas the Arabic abstracts include from one to five paragraphs. Also, unlike the Arabic texts, the introduction and abstract sections are more related in English in the field of Sociology in terms of move 1 'establishing a territory' and move 2 'establishing a niche'. Alotaibi's dissertation differs from the current study because it examines disciplinary differences in the introductions and abstracts of RAs.

In another study that supports Alotaibi's findings, Alhuqbani (2013) examined the disciplinary differences between Arabic RA abstracts across four disciplines: Law, Linguistics, Medicine and Police using Bhatia's (1993) and Hyland's (2000) move structures. Alhuqbani found out that there are disciplinary differences between the abstracts in terms of their adherence to these models. Alhuqbani clarified that while the abstracts in Medicine adheres to these models, the abstracts in Linguistics, Law and Police do not. The only obligatory move, as Alhuqbani mentioned, occurring in all abstracts, is the purpose move among introduction, method, results and conclusion moves.

Methodology has not been given attention similar to the introduction section, although it can be considered the backbone of conducting empirical research. The reports of this research describe how a study was conducted and how it may affect the research results (Weissberg and Buker 1990). Lim (2006) observes that the methods section is important for several reasons: 1- to connect a research method with previous procedures or with the other sections of the research; 2- to strengthen the credibility of the results; 3 - to persuade readers of the validity of the instruments utilised to obtain the results; 4- to prevent possible challenges to research designs; and 5- to avoid uncertainties about results and relevant explanations. In addition, it is the information given about empirical method which makes a piece of research replicable. Therefore, as Mur-Dueñas (2007) states, methodology plays a major role in writing a successful RA. However, there are no studies, to the best of the researcher's knowledge, which have dealt with the rhetorical structure of accounts of methodology of Arabic RAs in the field of Curricula and 
Methods of Instruction. Furthermore, the present research relies on using the transitivity framework which, as far as the researcher knows, has not been applied to the RA methodology.

There are some studies which examined the move structure of the methods section in English RAs. For example, Musa et al. (2015) identified the moves of 60 method sections in the field of Biomedical Engineering. Kafes (2016) compared the method sections of MA theses written by novice Turkish writers and RAs written by expert Turkish writers. The only move structure which describes the rhetorical structure of the methods section of RAs written in Arabic is Najjar's (1990). He analysed the rhetorical and linguistic components of 48 method sections in the sub-fields of agricultural sciences: Soil, Plant Production, Plant Protection and Animal Production Sciences. The components that Najjar found out are: '1- Establishing time and place of study; 2- Re-announcing purpose(s) of study; 3- Describing investigated sample(s); 4- Describing study design; 5- Describing investigative and experimental procedures; 6- Describing statistical procedures for data assessment' $(1990,149)$.

Najjar did not only analyse the methods section in his study, but he also investigated the other sections conventionally found in RAs; introduction, results and discussion. As he concentrated his attention on the introduction section, the methods section was not the main focus in his analysis. This makes his study different from the scope of the current study. Another difference is that the discipline considered in Najjar's dissertation belongs to the scientific field, while the discipline considered in this study belongs to social sciences. Variation across these disciplines may arise. Swales and Feak maintain that 'methods are very variable across the disciplines' (2004, 224). Moreover, Najjar conducted his analysis in 1990, so it might be considered important to update the analysis of the generic structure of RA methods as genres may change over time (Swales and Najjar, 1987).

\subsection{Purpose and objectives of the study}

The purpose of this study is to examine the methodological elements of Arabic educational RAs. This is to be realised by achieving the following objectives:

1- To analyse the rhetorical structure 'moves and steps' of accounts of methodology in the field of

Education, specifically in Curricula and Methods of Instruction.

2- To identify the linguistic exponents which realise the moves and steps and show how they are put together.

\section{Research Method}

\subsection{Database and selection criteria}

The database for this study consists of 40 method sections in the area of Curricula and Methods of Instruction. These sections were selected from RAs published in refereed Arabic journals in the field of Education. Articles in Curricula and Methods of Instruction are published in educational journals. The RAs included in this study met the following criteria: 1- The Arabic articles were written by authors affiliated with Arab universities; 2- All RAs belong to the discipline of Curricula and Methods of Instruction; 3- All articles are experimental or quasi-experimental; 4- All articles were published within a time span of two years (2013-2014), readily available at the time of the data collection; and 5- All articles 
Genre Analysis of Accounts of Methodology in Arabic

Educational Research Articles

were published in journals that are likely to have an influence in the field of Education and are also likely to have a large and wide (though not necessarily the largest) readership.

Two Jordanian experts in the field of Education were consulted to recommend the journals. One of the experts is a member in the editorial board of a Jordanian journal and the other is an associate professor in Curricula and Methods of Instruction. These experts recommended the following three journals: 1Almajalah al'urduniyah fii al9uluum altarbawiyah: The Jordanian Journal of Educational Sciences (JJES). 2- Almajalah aldawliyah Il'abHaath altarbawiyah: The International Journal for Research in Education (IJRE). 3- Majalat al9uluum altarbawiyah wa alnafsiyah: Journal of Educational and psychological Sciences (JEPS). The members of the consultative board of these journals are professors from well-regarded and international universities located across the Arab world, in the United States and in the United Kingdom. These journals are international, refereed and bilingual. Researchers can publish their articles in either English or Arabic and their papers are considered for promotional purposes.

The RAs were collected from the Arabic journals in 2013 and 2014, as shown in table 1 below.

Table 1: Total number of Arabic RAs.

\begin{tabular}{lccc}
\hline Journal & $\begin{array}{l}\text { No. of RAs in } \\
2013 \text { that matches } \\
\text { the criteria }\end{array}$ & $\begin{array}{l}\text { No. of RAs in } \\
\text { 2014 that matches } \\
\text { the criteria }\end{array}$ & $\begin{array}{l}\text { Total number of } \\
\text { selected }\end{array}$ \\
\hline JJES & 6 & 6 & 12 \\
IJRE & 2 & 8 & 10 \\
JEPS & 8 & 10 & 18 \\
& & & 40 \\
\hline
\end{tabular}

\subsection{Analytical framework}

The framework that has been initially used in this study is Nwogu's $(1997,135)$ outline for the methods section of medical RAs. The outline consists of the following moves and constituent elements:

Move 1: Describing Data-Collection Procedure

1-1 Indicating source of data

1-2 Indicating data size

1-3 Indicating criteria for data collection

Move 2: Describing Experimental Procedures

2-1 Identification of main research apparatus

2-2 Recounting experimental process

2-3 Indicating criteria for success

Move 3: Describing Data analysis Procedures

3-1 Defining terminologies

3-2 Indicating process of data classification

3-3 Identifying analytical instrument/procedure

3-4 Indicating modification to instrument/procedure

Nwogu's outline was initially applied to a sample of three Arabic RAs, one article from each journal. It was found that his outline does not accommodate the data under investigation because some moves and 
steps in the outline do not match with the sample. As a result, bottom-up processing was employed by exploring the linguistic features and deciding what step they can represent and under what move a step falls (for more information on employing bottom-up processing, see the section 'procedures of analysis' below). The outline was inductively developed by adding some moves and steps which appeared to become necessary for representing the methodology.

The following are the modifications which were performed at the level of moves and resulted in changing the constituent steps: the first move, 'Describing data-collection procedure' is replaced by the move 'sample of study'. The modified version contains 'sample of study' as the first move which consists of the following steps: 1- 'size of sample'; 2- 'study population'; 3- 'setting and site of study'; 4'characteristics of sample'; and 5- 'sampling technique/design'. The second move is identical to Nwogu's, namely, 'procedures of study'. Under this move, the steps 1- 'design of study'; 2'implementing of an intervention or a material'; and 3- 'identifying interventionists' are added. The third move, 'measure' consists of the following steps: 1- 'construction of a measure'; 2- 'validity and reliability of the measure'; and 3- 'scoring procedures'. The last move, 'data analysis procedures' is the same as the third in Nwogu's, but with differences between the constituting steps. It is composed of 1- 'statistical test' and 2- 'performing preliminary analysis'.

\subsection{Procedures of the analysis}

The data analysis was conducted based on Swales' (1990) move analysis approach to identify the moves and steps of the methodology by reading and understanding the general purpose of the texts and the specific rhetorical function of text segments. I then began matching the moves and steps from Nowgu's (1997) outline with my data. As mentioned above, I used a sample of three Arabic RAs and found that the present sample does not match with some moves and steps from Nwogu's, which resulted in modifying the outline.

The modification of Nwogu's outline occurs in a bottom-up processing by starting at the bottom level with analysis of the linguistic elements: the lexico grammatical features to help determine the steps and then the moves (for the desirability of employing both top-down and bottom-up processing, see Tawalbeh 2019). These features were described using the systemic functional grammar approach (Halliday 1985). Halliday and Matthiessen (1999) demonstrate that there are three metafunctions for making meaning: ideational, interpersonal and textual, which are all realised in the lexicogrammar system. The focus of the current analysis is on identifying the components of ideational meaning; participants, processes and possibly circumstances, which form the transitivity system (Halliday 1985).

In the analysis of the linguistic features, transcription and word by word translation are given under some examples to give a clearer image of the original construction and word order employed in the Arabic examples. The transliteration was conducted based on the transcription system used in Najjar's (1990) study.

The second level in bottom-up processing includes making inferences about the function of text segments to assign steps for the linguistic constructions. The third level investigates what purpose a set of steps can share to classify them under a move. A small number of steps and moves from my data were 
Genre Analysis of Accounts of Methodology in Arabic

Educational Research Articles

matched with the ones in Nwogu's (1997) outline, while several new ones were added to the outline. This modified version was applied to all of the sample, to which the same series of bottom-up steps, as described above, were applied. The resulting moves and steps were matched with those in the modified outline. This stage includes adding any new moves or steps to the modified outline if there was no match with the existing ones. The fourth level ends with one final modified outline.

Finally, to obtain reliability of move analysis, a rater participated in analysing the data. The rater is a $\mathrm{PhD}$ candidate in Linguistics. Two training sessions of two hours each were conducted to make sure that the rater knew how to analyse the data. The rater was asked to use the last modified framework to assign the sentences, clauses or phrases to a move or a step type. And then, the rater and I discussed the findings of the analysis and resolved small discrepancies.

\section{Results and Analysis}

The generic analysis reveals the moves and steps that occur in all texts analysed, as can be seen in table 2 below.

Table 2: The moves and steps of the methodology in the Arabic RAs.

\begin{tabular}{ll}
\hline Moves & Steps \\
\hline & 1- Size of sample \\
& 2- Characteristics of sample \\
& 3- Sampling technique/design \\
1- Sample and Population of study & 4- Time of study \\
& 5- Setting and site of study \\
& 6- Population of study \\
& 1- Design \\
& 2- Introducing an intervention or a material \\
& 3- Designing and implementing an \\
& intervention or a material \\
& 4- Identifying interventionists \\
& 5- Recounting procedures \\
& 1- Construction of a measure \\
& 2- Validity of the measure \\
& 3- Reliability of the measure \\
3- Measure & 4- Scoring procedures \\
& 1- Statistical tests \\
4- Variables of study & 2- Preliminary analysis \\
\hline
\end{tabular}

\section{Move 1: Sample and population}

The first step, 'size of sample' gives the number of participants, classes or schools included in or excluded from participating in a study. For example:

$$
\text { 'أصبح العدد بعد استبعاد الغياب } 50 \text { طالبا في المجموعة الضابطة، } 48 \text { طالبا في المجموعة التجريبية'. }
$$

1- After excluding for absence, the number became 50 male students in the control group and 48 male students in the experimental group. 
This example realises also the second step, 'Characteristics of sample' by presenting the gender of participants. There is a relational process type in this example represented by the verb 'became'; 'the number' is the token and the size and characteristics of sample are the value. The use of this verb highlights the establishment of sample size as a developing process and thus draws attention to the researchers' process. The use of this verb presents the data collection process as narrative.

This step is also represented by a material process type, as in:

$$
\text { 'بلغ عدد الطلبه الحاضرين في الصف } 23 \text { طالبا، تسرب منهم طالب واحد'. }
$$

2- The number of students present in the class reached 23 male students; one of them dropped out.

$$
\text { 'وقد قام الباحثان باختيار عينة الدارسه المكونه من (r7) طالبا من طلاب الصف الخامس الأساسي'، }
$$

3- The two researchers selected the study sample composed of 62 male students from the fifth elementary grade.

The material process in 2 and 3 is realised by 'dropped out' and 'selected', respectively. In 2, the 'student' is the actor playing an active role in leaving the study and changing the sample size. In 3 , it is the 'two researchers' who engage in the process of selection and decide on the sample size.

Step 3, 'sampling technique/design' tells how the sample is selected and is represented as the goal or the circumstance for a material process type.

$$
\text { 'تمم اختيارهم بطريقة قصدية '. }
$$

4- tamma 'ikhtiyaaruhum bi Tariiqatin qaSdiyatin.

4- done selecting them by a method deliberately.

4- They were deliberately selected.

The sampling method is given here in the circumstance, 'bi Tariiqatin qaSdiyatin' for the material process 'done selecting', which shows an alternative for expressing the passive form by using the verb 'تم' 'tamma' which has the meaning of 'done'. It is in an active form, but it functions as passive showing that the process of selection was accomplished. This verb is followed by the gerund 'اختيار' 'selecting' which expresses the action and has the role of the grammatical subject, but it does not function as an actor. The actor is absent supporting the passive form of the sentence.

Step 4, 'Time of study' specifies the time of selecting the sample or the time of implementing the experiment. As for step 5, 'the setting and site of study', it gives information about the place from which the sample was selected and where the experiment was conducted. These two steps are realised in the circumstance for material and relational processes. The material process is represented by the construction of 'tamma' and a gerund, as exemplified below:

'تم اختيار أفراد الدراسة من طلبة الصف الثالث الأساسي، من المدارس التابعه لمديرية التربية والتعليم في محافظة اربد، للعام الدراسي 2012/2011'

5- tamma 'ikhtiyaaru 'afraadi '...'

5- Done selecting members '...'. 
Genre Analysis of Accounts of Methodology in Arabic

Educational Research Articles

5- The study members were selected from third elementary grade students from the schools in the Irbid Directorate of Education in the academic year 2011/2012.

Step 6, 'population of study' tells whom the sample is selected from. It is most often introduced by a relational process using the noun phrase 'study population' as a possessor and the members of which (the possessed) are preceded by the prepositional phrase 'from all', as seen below:

$$
\text { 'تكون مجتمع الدراسة من جميع طلبة الصف السادس الأساسي'، }
$$

6- takawana mujtama9u aldiraasati min jamii9 Talabati '...'.

6- Consisted population the study from all students '...'.

6- The study population consisted of all sixth elementary grade students.

To sum up, one higher phase in bottom-up processing is to reveal the move type within which the above steps fall. It can be seen that the preceding steps provide information relevant to the sample of a study, so they all share one overall purpose which is to detail the participants of a study and how they are selected. Therefore, they are assigned under the move, 'sample and population of study'.

\section{Move 2: Procedures of study}

The first step is the 'design' which is realised by giving the name of the design or by presenting procedures that explain the design. The design of a study is set as the goal for a material process, as in:

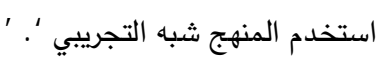

1- The quasi-experimental design was used.

Step 2, 'introducing an intervention' is realised by providing a definition, features and/or aims of the intervention used in a study. For example:

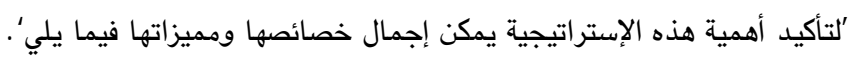

2- lita'kiidi 'ahamiyati hadhihi al'istratiijiyah yumkinu 'ijmaalu

2- To confirm importance this the strategy can be summarising

khaSaaiSiha wa mumayizatiha fiimaa yalii:.

characteristics its and features its in the following.

2- In order to confirm the importance of this strategy, its characteristics and features can be summarised as follows.

Example 2 includes a similar case to 'tamma' and a gerund; the verb 'yumkinu' is in an active form, which functions as hedging. It is followed by the gerund (summarising) which is the grammatical subject. The process of summarising forms the action whose actor is absent and whose goal is 'characteristics and features'. Therefore, the construction of 'yumkinu' and the gerund 'summarising' works as a passive formation which means that the summary can be done.

The third step is 'designing and implementing the intervention or the material' which shows that the researchers in all of the articles create an intervention or a material. This step is realised by the following sub-steps: 1- reviewing available literature and sources about the intervention or material; 2- using a tool to design them; 3- establishing the components of the intervention or material and describing the 
Tawalbeh

procedures for implementing them; and 4- checking the validity and reliability of the intervention or material. It was found that all process types except the behavioural and the existential appear within this step. For example, there is a mental process in the example below which explains a procedure of implementing an intervention:

$$
\text { 'تثاهد الطالبات مقطع فيديو'. }
$$

3- The female students watch a video clip.

Another example below shows two different processes which are: a verbal process represented by 'is done discussing' and a material process represented by 'adding':

$$
\text { 'ثم يتم مناقثة وإضافة تفاصيل الى القصة وتوسيعها'، }
$$

4- thuma yatimmu munaaqashatu wa 'iDaafatu tafaSiil ilaa alqiSati wa tawsii9iha.

4- Then is done discussing and adding detail to the story and elaborating it.

4- Then, the story is elaborated by discussing and adding detail to it.

Step 4 is 'identifying the interventionist'. It points to who implements the intervention or the experiment and the rationale of selecting the interventionist. The example below introduces the interventionist as the actor for the material process 'taught':

$$
\text { 'قام أحد الباحثين (الباحثة) بتدريس المجموعات'. }
$$

5- qaama 'aHadu albaaHithayni (albaHithah) bitadriisi

5- Performed one the two researchers (the female researcher) in teaching

almajmuu9aati.

the groups.

5- The female researcher taught the groups.

This example shows the use of an alternative way to express the same meaning of the verb 'taught'. The Arabic version of this example represents the material process using the verb: 'qaama' and the prepositional phrase: 'bitadriisi'. In Arabic, this construction means that the researcher performed the action of teaching. It relies on delaying the action to the prepositional phrase resulting in a longer sentence with apparently redundant words. The verb 'qaama' carries no significant meaning in the sentence.

The interventionists are introduced in other examples using the passive construction of 'tamma' and a gerund, which indicates that the interventionists were prepared to implement the intervention, as in:

$$
\text { 'وقد تم تدريب المعلمة على تدريس البرنامج'. }
$$

6- wa qad tamma tadriibu almu9alimati 9alaa tadriisi albarnaamaj.

6-And done training the female teacher to teaching the program.

6- The female teacher was trained to teach the program.

'The female teacher' is put as the goal for the material process 'was trained' indicating that the teacher was prepared to implement the intervention.

Step 5 is 'recounting the procedures of the study'. It mentions the procedures followed in conducting the whole experiment. This step occurs in the RAs after the third move 'Measures', but it is presented 
Genre Analysis of Accounts of Methodology in Arabic

Educational Research Articles

here because it includes procedures; therefore, it is considered as part of the second move. It is realised by a number of sub-steps which explain what is done in the pre-experiment phase, during the experiment phase and post-experiment phase. These sub-steps are summarised as they appear in the RAs in the following order: 1- considering ethical principles; 2- selecting the sample; 3 - selecting and designing the material or the intervention; 4- establishing the measure; 5- Preparing the interventionist; 6- administering the measure (pre-test); 7- conducting the experiment; 8- administering the measure (post-test); and 9collecting the data. By announcing these steps, the writers follow a writer responsibility approach as they guide their readers in a step by step description. The writers have already discussed the sub-steps: 2, 3, 4, 6, 7 and 8 in previous texts (under the sample, intervention and measure) and they repeat them within this step.

Almost all of the above sub-steps are discussed under the other moves except for 1 and 7. Sub-step 1 is represented using nouns like 'approval' and verbs as 'address' and 'obtain', as in:

$$
\text { 'تم رسميا مخاطبة جميع المدارس' ....' وأخذ الموافقة'. }
$$

7- tamma rasmiyan mukhaaTabatu jamii9i almadaarisi '...' wa 'akhdhu almuwaafaqati.

7- Done officially addressing all the schools '...' and obtaining the approval.

7- A- All schools were officially addressed... B- and approval was obtained.

'حصل الباحثان على المواققات الرسمية'،

8- The two researchers obtained official approvals.

The first example uses the passive formation of the verb 'tamma' and the gerunds 'addressing'/ 'obtaining' representing material processes. In 8 , there is also a material process signalled by the verb 'obtained', but it is in an active form and has immediate agents 'the two researchers', who already engaged in a process of communication with concerned parties to realise the ethical principles.

Sub-step 7 is to conduct an experiment by applying an intervention to an experimental group and using a traditional method to teach a control group. This sub-step is represented using the material processes 'teach'/ 'apply' in passive formation. For example:

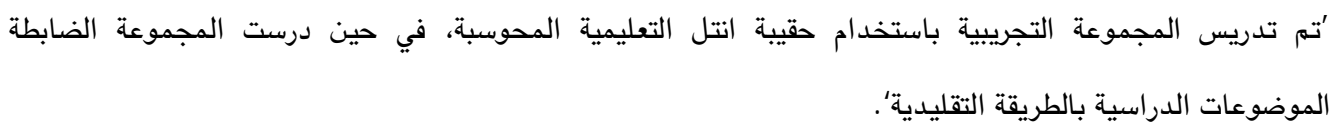

9A- tamma tadriisu almajmuu9ati altajriibiyati '...'.

9A- Done teaching the group the experimental '...'.

9A- The experimental group was taught using computerised instructional package (Intel) while

9B- durrisat almajmuu9atu alDaabiTau nafsi almawDuu9aati '...'.

9B- Was taught the group the control same the lessons '...'.

9B- the control group was taught the same lessons by the traditional method.

The Arabic RAs follow the same formation given in this example by using 'tamma' with the gerund 'teaching' (9A) and the passive voice (9B). 
It can be noted from the above steps that the writers of the RAs describe the procedures to allow replications for future studies. This overall purpose can justify the move type assigned to these steps as 'procedures of study'.

Move 3: Measure

This move identifies the tool used to measure the variables of a study. It is realised by a number of steps. The first is 'construction of a measure'. Firstly, the researchers identify the measure used by displaying its name and determining the purpose of the measure. This reveals the rationale of establishing the measure.

$$
\text { 'إختبار التفكير الإبداعي الرياضي }
$$

1- A- Mathematical creative thinking test

B- The researcher prepared a test to measure class teacher students' skills in mathematical creative thinking.

$$
\text { 'تم اعداد الإختبار من قبل الباحث بطريقة موضوعية (الإختيار من متعدد)'، }
$$

2- tamma 'i9daadu al'ikhtibaari min qibali albaaHithi biTariiqatin mawDuu9iyatin.

2- Done preparing the test by the researcher in method objective.

2- The test was objectively prepared by the researcher (multiple choice).

Example $1 \mathrm{~A}$ gives the name of the measure and $1 \mathrm{~B}$ states the purpose of the test, which is to measure the dependent variable: the 'students' skills...'. The writer of this example specifies the variable based on which he prepared the measure. Determining the purpose is the first step in constructing a measure. The purpose of the test in $1 \mathrm{~B}$ is the circumstance for the material process 'prepared' whose actor is 'the researcher'. Example 2 shows the use of agentive passive because it has its agent in the prepositional phrase 'min qibali' which occurs after the passive construction. The circumstance in this example describes how the test was prepared.

The process of measure preparation in nearly half of the articles is based on referring to other relevant studies as a source to help the researchers themselves establish or develop the measure. In addition, establishing the measure contains determining the number of items, their type and which topics the items measure. Most of the articles use a relational process to present the number and type of test items, as in:

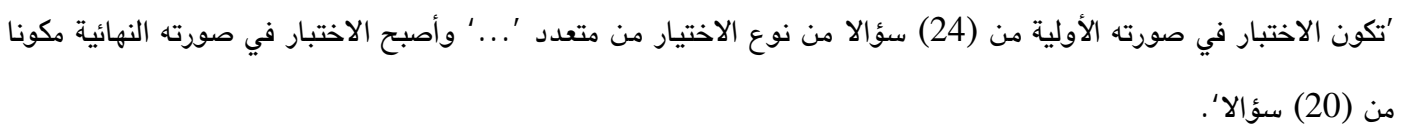

3- A-The test in its initial form consisted of 24 multiple choice questions '...'.

B- The test became 20 questions in its final form.

In example 3A, the number of items and the test type are possessed in relational possessive process. The number of items declined to ' 20 ' in $3 \mathrm{~B}$ showing that it went in a procedure expressed by the verb 'became'. This example can draw readers' attention to the way in which the measure was constructed as a developing process presented as narrative. 
The type of test items appears as the circumstance for a material process type in a few articles using the verb 'tamma' and the gerund 'formulating'. An example is:

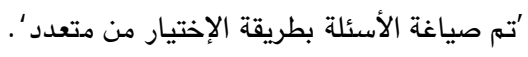

4- tamma Siyaaghatu al'as'ilati biTariiqati al'ikhtiyaari min muta9adid.

4- Done formulating the questions in form the choice from multiple.

4- The questions were formulated in a form of multiple choice.

Finally, the construction process ends with including instructions about how to complete the test.

The second step, 'validity of the measure' is achieved by consulting referees or specialists in the field and considering their comments or suggestions to make amendments on the measure if needed. The verbs used to realise this step are of a material process type, as exemplified in:

$$
\text { 'تحقق الباحثون من الصدق الظاهري للمقياس بعرضه على ثمانية محكمين'. }
$$

5- The researchers checked the face validity of the measure by presenting it to eight referees.

The third step is 'testing the reliability of the measure' which is confirmed by administering the measure on a pilot sample and then showing a report about the measure reliability. The example below demonstrates the realisation of this step:

$$
\text { على العينة الاستطلاعية'، 'حسب معامل الثبات بطريقة الإختبار وإعادة تطبيق الإختبار }
$$

6- Reliability coefficient was calculated by testing and retesting the pilot sample.

There is a material process 'Husiba: was calculated', goal 'Reliability coefficient' and the way in which reliability is calculated is in the circumstance. Values of reliability of a measure are reported using a relational process, as in:

$$
\text { 'بلفت قيمة معامل الثبات (0.87)' . }
$$

7- The value of the reliability coefficient reached 0.87 .

Most articles do the same as this example in using the verb: 'balagha': reached, highlighting the establishment of measure reliability as a narrative process. This example reports the value of reliability using an identifying relational process 'reached', the token is 'the value...' and the value is ' 0.87 '.

Step 4, 'scoring procedures' is represented by assigning values to the items of the measure (as noticed in the italicised relative clause in the example below) and using a material process type:

$$
\text { 'اتبع نظام التصحيح الذي يمنح درجة (1) واحد للإجابة الصحيحة'. }
$$

8- The scoring method which gives one score for the correct answer was followed. (my italics)

In this example, 'the scoring method' is the goal for the material process 'was followed'.

The steps above share one purpose which is to detail the assessment method of measuring variables. Therefore, the move type, 'measure' is used to represent these steps. 
Move 4: Variables of study

The purpose of this move is to specify which variable is the force described as independent, and which is the result of that force described as dependent. This move is represented most often using a relational process type, as in:

$$
\text { 'أما متغيرات الدراسة فهي: أ- المتغير المستقل:'...' ب- أما المتغيران التابعان فهما'. }
$$

1- The variables of the study are: a- the independent variable '...' b- the two dependent variables are.

There is an identifying relational process in this example wherein 'the variables' are the token, and the independent variable is the value. In a very small number of cases, the variables of a study are realised using a material process, as seen below:

$$
\text { 'تناولت الدراسة المتغيرات الاتية' . }
$$

2- The study tackled the following variables.

Move 5: Data analysis procedures

The first step presents the statistical tests used in analysing the data and it is realised in most of the articles by the material process of 'tamma' with a gerund, as in:

$$
\text { 'تم استخراج المتوسطات الحسابية والانحرافات المعيارية'. }
$$

1- tamma 'istikhraaju almutawasiTaati alHisaabiyati wa al'inHiraafaati almi9yaariyati.

1- Done extracting the means and the deviations the standard.

1- The means and the standard deviations were extracted.

The second step is to perform preliminary analysis, which is reported by making sure that the groups of study (the experimental and the control) are equivalent in their level of achievement in a pretest and/or in their age. The examples below show how this step is presented:

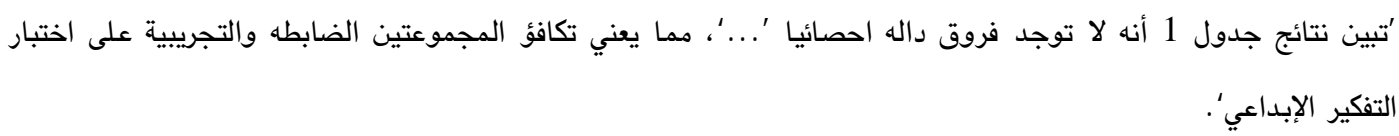

2- '...', mimaa yu9nii takaafu'u almajmuu9atayn alDaabiTah wa altajriibiyah '...'.

2- '...', which means equivalence the two groups the control and the experimental '...'.

2- Results of table 1 demonstrate that there are no statistically significant differences '...', which means that both the experimental and the control groups are equivalent in the creative thinking test. (my italics)

'يتضح من الجدول 1 أنه لاتوجد فروق ذات دلالة إحصائية '...'، وبالتالي يمكن القول: إن طالبات المجموعتين التجريبية

$$
\text { والضابطة متكافئان قبل البدء في تطبيق المعالجة التجريبية'. }
$$

3- It is clear from table 1 that there are no statistically significant differences '...' ; therefore, it can be said that the female students of both the experimental and the control groups are equivalent before implementing the experiment. (my italics).

The two examples include existential processes to display the results of the analysis. The results (in italics), stating that the groups are equivalent, are put as a value for the relational process 'means' in 2 , while in 3 they are the verbiage for the verbal process 'can be said'. 
Genre Analysis of Accounts of Methodology in Arabic

Educational Research Articles

The above steps fall under the move, 'data analysis procedures' because they all share one purposeto explain what was done to analyse the data.

\section{Discussion}

To serve the genre analysis of the methodology of Arabic RAs, this study seeks to answer the following significant question: What is the rhetorical structure of accounts of methodology in the field of Curricula and Methods of Instruction? This leads to ask the following sub-questions: 1- What are the moves and steps of accounts of methodology?; 2- What is the sequencing of these moves and steps?; 3Where are they located in the RAs?; and 4- How are they realised (linguistic exponents)?

The present study reveals that the methodology of Arabic educational RAs can be analysed in terms of moves and steps which shape the structure of the texts analysed. The analysis shows that there are five moves representing the methodology: 1- sample and population of study; 2- procedures of study; 3measure; 4- variables of study; and 5- data analysis procedures. Each move is realised by a number of steps, as shown in table 2. The moves and steps found in this study are not similar to the ones found in Nwogu's (1997) study. There are many steps and sub-steps that occurred in the current study sample but are not found in Nwogu's, such as 'sampling design', 'place and time of study', 'design of study', 'designing and implementing an intervention or a material' and move 3 'measure' with its constituent steps. The appearance of more steps in the present study may be due to the fact that this study conducted a detailed analysis of the accounts of methodology, while Nwogu's study focused on the entire RA.

The following steps from Nwogu's framework of the methods of medical papers do not exist in my data: 'indicating criteria of success', 'defining terminologies' and 'indicating modification to instrument/procedure'. These steps might be considered as features relevant to the experiments conducted in the medical field. Therefore, the differences between the methodological elements analysed in the current study and in Nwogu's study might also be attributed to disciplinary differences between medical and educational RAs. This finding is supported by Samraj (2002), Lakic (2010), Peacock (2011), Briones (2012) and Kanoksilapatham (2012), who found out some rhetorical differences across different disciplines. However, it could be claimed that the steps which Nwogu lists are still valuable in Education. They might occur in other sections of the RAs in the current study sample.

The sequencing of moves is as presented in the results section (1- sample and population of study; 2procedures of study; 3- measure; 4- variables of study; and 5-data analysis procedures). There is an alternative pattern in which the procedures and measure are swapped around and it occurs in $65 \%$ of the RAs. The Arabic RAs present the move, 'variables of the study' at either the start of the above sequence or just before 'data analysis procedures'.

With the exception of the 'measure' move, there is no discernible regularity to the order in which the steps within each move appear. Some of the steps from the sample move are sometimes presented as part of the procedures move, or even in the introduction section of the article. Some steps from the procedures move are presented as part of the sample move, or appear just before it. The steps, 'size of sample' and 'sampling design' reoccur within the second move, 'procedures' in a few RAs. The steps which show the 
time and setting of studies are given in the introduction section and are repeated within the sample move. The first step, 'design of study' of the second move, 'procedures' appears before the sample in nearly half of the articles. The step, 'recounting procedures' occurs after the measure allowing for some steps to appear again. These steps restate that the sample was selected, the material or the intervention was designed and the measure was established and administered. Thus, the importance of move 2, the 'procedures', as the core of the RAs analysed in this study, can give its steps flexibility to be found under different categories in the methodology.

The above observations indicate that repetition of steps is not uncommon. It is possible that this repetition is a reflection in written discourse of the traditional practice in Arabic oral discourse of using it to establish rhetorical credibility. The writer's credibility is (thought to be) enhanced because, by demonstrating his/her consistency in the presentation of information, it underlines the veracity of that information. In addition, it indicates a real desire to communicate with the reader (to get the reader to follow the discourse). More generally, it could be said that credibility is enhanced simply by demonstrating that the writer is familiar with conventions of rhetoric in Arabic.

The analysis of sequence reveals that some of the moves and steps realising the accounts of methodology can appear in other sections of RAs. For example, move 4, 'variables of study' and some other steps occur sometimes in the introduction sections. These steps are as follows: 'size and characteristics of sample', 'place and time of study' and 'designing and implementing an intervention or a material'. The results section presents frequently the whole move, 'data analysis procedures' with one or both of its constituent steps. The variable position of all of these moves and steps indicates that accounts of methodology can be extended to sections of the RA other than the methods section. This phenomenon is perhaps a warning for readers who rely on the headings as the starting point to read and find the methodological elements of research as there could be readers who are interested in knowing only about the accounts of methodology of an RA. Those readers may begin reading only when they see a heading such as methods or procedures.

It appears that the steps are represented using all process types except the behavioural one. The existential process appears in a few cases and it is associated with presenting results of preliminary analysis. Verbal and mental processes realise a few steps; they mainly appear under the step 'implementing of an intervention' because the nature of the intervention used in a study helps such processes to exist. There can be an intervention which relies on viewing a material or giving the subjects of a study some information. These findings are similar to Paltridge's (1997), who found out that all process types, except existential and behavioural processes, occur in the 'background information' element in the introduction sections of the RAs he analysed. He affirmed that existential process occur in other parts of the introduction sections and predicted that behavioural process would occur if the subject matter of the RAs is different from the ones he dealt with. However, Paltridge $(1997,81)$ pointed out that 'no particular process type would always occur at specific points in the texts'. This is different from what this research reveals as there can be one process type that represents one step. For example, the steps, 'sampling design' and 'design of study' are represented using a material process type. 
Genre Analysis of Accounts of Methodology in Arabic

Educational Research Articles

The prevalent processes used to realise the steps are either material or relational. In some steps in different articles, both processes are used to realise one same step. The identifying relational process is realised within the steps, 'size of sample', 'number of measure items' and 'values of reliability', using the verbs 'became' and 'reached'. These verbs make the numbers and values in these steps as passing through a developing process presented as narrative.

Material processes are realised not only by verbs, but also by constructions which consist of the verb 'tamma': done and a gerund or the verb 'qaama': performed and a prepositional phrase. Material processes are represented most often by using passive formations and most of these formations are constructed as a consequence of having verbs in active form functioning in passive. The Arabic researchers have employed such verbs as an alternative to replace forms of active agency and passive voice and to avoid the use of personal pronouns. There is no single case of personal pronoun which refers to the researcher(s) in the data analysed. The researchers only ever refer to themselves in the 3rd person resulting in message-centred texts.

The analysis shows that there are some steps which are realised using similar linguistic choices across different articles. These steps/sub-steps are: 'population of study', 'citing literature to help design the intervention or the material', 'conducting the experiment' (as part of the step 'recounting procedures'), 'validity of the measure', 'reliability of the measure' and 'preliminary analysis'. It can be said that many Arab researchers follow each other in using a set of conventional established procedures represented by using similar linguistic exponents. For example, most Arab researchers test the validity of the intervention or the measure by presenting it to a group of referees. This is represented in texts by using the construction of 'tamma' with the gerunds 'presenting' and 'checking'. The similarity of the linguistic choices can indicate the uniformity of some text segments across different Arabic RAs. Therefore, readers can expect what the methodology of an Arabic educational article may include and what researchers do by having read a few articles in the field. The Arabic RAs display what Hua (2011) calls 'interpersonal harmony' which characterises the culture to which the Arab researchers belong as collectivistic. These researchers tend to belong to collective societies as they trust their in-groups' decisions and formulas and prioritise the groups' goals over the individual's goals (Samovar et al. 2011).

\section{Conclusion}

This study has examined the rhetorical features (moves and steps) and the lexico grammatical features of the accounts of methodology of Arabic educational RAs whose design is experimental or quasi-experimental. The analysis of moves and steps relies initially on using Swales' (1990) moves analysis approach and then uses bottom-up processing. This analysis shows that there are five moves representing the methodology: 1- sample and population of study; 2- procedures of study; 3- measure; 4variables of study; and 5- data analysis procedures. These are realised by some steps and sub-steps, as given in section 3. The lexico grammatical features are investigated using the transitivity framework which shows the semantic label and the types of processes used to realise one step. It is found that all process types except the behavioural one represent the methodological elements. However, the material or 
relational process realises many more steps/sub-steps than the other processes across different articles. This implies that the lexico grammatical features can be defining for this type of genre, namely, the methodology of RAs.

\subsection{Implications of the study}

The results of this study provide insights into Arabic academic discourse. They have some implications for research into academic discourse, for readers and writers of research and for pedagogy. Researchers may use the outline of moves and steps presented in this study to analyse the methodology of RAs across different disciplines. The application of the transitivity framework in this study raises a question about the usefulness of its applicability to the methodology of RAs whose design is other than experimental or quasi-experimental. Its usefulness can also be tested by applying it to different sections of RAs written in different languages.

The outline of moves and steps may benefit readers of RAs by building their expectations about what they will read in the methodology. It is also possible that beginner writers and students may benefit

from this outline by allowing them to follow the rhetorical features they need to compose their methodology. This, though, would require some adaptation so that these features could be added to textbooks and teaching materials. Teachers might refer to them to develop their teaching practices by teaching students how the methodology of experimental and quasi-experimental design proceed. 
Genre Analysis of Accounts of Methodology in Arabic Educational Research Articles

\section{تحليل الجنس الأدبيّ لمنهجيّة الأبحاث التربويّة العربيـة \\ أحمد طوالبة \\ تسم اللفة الإنجليزيّة، جامعة إربد الأهلية، الأردن \\ الملخص}

لقد أجرى محللو الأجناس الأدبية دراسات حول المقالات البحثية المكتوبة بلغات مختلفة مع إعطاء أهمية أساسية لقسم المقدمة. ولهم تحظ هذه المنهجية باهتمام مماثل على الرغم من أنها جزء أساسي من الأبحاث التجريبية. فلا توجد دراسات، في حدود ما أعلم، تناولت منهجية الأبحاث المكتوبة باللفة العربية. ولذلك، جاء هذا البحث هادفاً إلى تحديد السمات البلاغية لمنهجية الأبحاث العربية التربوية. ولتحقيق هذا الهدف، اختارت الدراسة 40 قسمًا من منهجية الأبحاث المنشورة في مجلات عربية محكمة في المجال التربوي. وقد تم تحليل هذه البيانات بناءً على منهج سويلز (1990) الخاص بالسمات البلاغية، وبناءً على عملية تحليل الأسلوب التصاعدي من القاعدة إلى الأعلى. وقد تم تحليل السمات اللغوية المكونّة للسمات البلاغية باستخدام نموذج التعدي (هاليدي، 1985). وأوضحت نتائج الدراسة أن هناك خمس مكونات تمثل المنهجية وهي: 1- عينة الدراسة ومجتمعها 2- إجراءات الدراسة 3- أداة القياس 4- متغيرات الدراسة 5- إجراءات تحليل البيانات. تتكون هذه العناصر من أجزاء أخرى فرعية تم تمثيلها في أغلب الأحيان باستخدام أسلوب الحدث/الفعل والأسلوب العلائقي. وتقدم نتائج هذا البحث نظرة عن الخطاب العربي الأكاديمي، وقد تساعد النتائج أيضًا في تقوية الكتاب الأكاديميين المبتدئين وتعزيز مقررات الكتابه. الكلمات المفتاحية: منهجية البحث، مقالات بحثية، التراكيب البلاغية، نموذج التعدي. 
Tawalbeh

\section{References}

Alhuqbani, Mohammed. 2013. Genre-Based Analysis of Arabic Research Article Abstracts across Four Disciplines. Journal of Educational and Social Research 3 (3): 371-382.

Alotaibi, H. 2013. Research Article Abstracts and Introductions: A Comparative Genre-Based Study of Arabic and English in the Fields of Educational Psychology and Sociology. PhD diss., retrieved from ProQuest. (UMI No. 3595269).

Al-Qahtani, A. A. 2006. A contrastive Rhetoric Study of Arabic and English Research Article Introductions. $\mathrm{PhD}$ diss., retrieved from: http://eprints.kku.edu.sa/id/eprint/185.

Biber, Douglas, Ulla Connor, and Thomas A. Upton. 2007. Discourse on the Move: Using Corpus Analysis to Describe Discourse Structure. Amsterdam: John Benjamins Publishing Company.

Briones, Roy R. 2012. Move analysis of philosophy research article introductions. Philippine ESL Journal 9: 56-75.

Connor, Ulla and Anna Mauranen. 1999. Linguistic Analysis of Grant Proposals: European Union Research Grants. English for Specific Purposes 18 (1): 47-62.

Fakhri, Ahmed. 2004. Rhetorical properties of Arabic research article introductions. Journal of Pragmatics 36: 1119-1138.

Flowerdew, John. 2013. "Introduction: Approaches to the Analysis of Academic Discourse in English". In Academic discourse, ed. John Flowerdew, 1-17. London \& New York: Routledge.

Halliday, Michael. 1985. An introduction to functional grammar. London: Edward Arnold.

Halliday, Michael and Christian Matthiessen. 1999. Construing Experience through Meaning: A Language-Based Approach to Cognition. London \& New York: Continuum.

Holmes, Richard. 1997. Genre Analysis, and the Social Sciences: An Investigation of the Structure of

Research Article Discussion Sections in Three Disciplines. English for Specific Purposes, 16 (4): 321337.

Hua, Zhu. 2011. "Introduction: Themes and Issues in the Study of Language and Intercultural Communication". In The Language and Intercultural Communication Reader, ed. Zhu Hua, 114. London: Routledge.

Kafes, Hüseyin. 2016. Generic Structure of the Method Sections of Research Articles and MA Theses by Turkish Academic Writers. International Journal of Language Academy 4 (3): 132-145.

Kanoksilapatham, Budsaba. 2005. Rhetorical structure of biochemistry research articles. English for Specific Purposes 24 (3): 269-292.

Kanoksilapatham, Budsaba. 2012. Research Article Structure of Research Article Introductions in Three Engineering Subdisciplines. IEEE Transactions on Professional Communication 55 (4): 294-309.

Lakic, Igor. 2010. Analysing Genre: Research Article Introductions in Economics. Journal of Linguistic Intercultural Education 3: 83-99. 
Genre Analysis of Accounts of Methodology in Arabic

Educational Research Articles

Lim, Jason. 2006. Method Sections of Management Research Articles: A Pedagogically Motivated Qualitative Study. English for Specific Purposes 25 (3): 282-309.

Mur-Dueñas, Pilar. 2007. A Cross-Cultural Analysis of the Generic Structure of Business Management Research Articles: The Method Section. Odisea 8: 123-137.

Musa, Nurul F., Noorli Khamis and Jano Zanariah. 2015. The Structure of Method Section in Engineering Research Articles. Asian Social Science 11 (17): 74-82.

Najjar, H. 1990. Arabic as a Research Language: The Case of the Agricultural Sciences. PhD diss., retrieved from ProQuest. UMI No. 9023607.

Nwogu, Kevin. 1997. The Medical Research Paper: Structure and Functions. English for Specific Purposes 16 (2): 119-138.

Paltridge, Brian. 1997. Genre, Frames and Writing in Research Settings. Amsterdam; Philadelphia: John Benjamins Pub. Co.

Peacock, Matthew. 2011. The Structure of the Methods Section in Research Articles across Eight Disciplines. Asian ESP Journal 7 (2): 99-124.

Samovar, Larry, Richard Porter and Lisa Stefani. 2011. "Hofstede's Value Dimensions and Hall's High

Context/Low Context". In The Language and Intercultural Communication Reader, ed. Zhu Hua, 4958. London: Routledge.

Samraj, Betty. 2002. Introductions in Research Articles: Variations across Disciplines. English for Specific Purposes 21 (1): 1-17.

Swales, John. 1981. Aspects of Article Introductions. Birmingham: University of Aston.

Swales, John. 1990. Genre Analysis: English in Academic and Research Settings. Cambridge: Cambridge University Press.

Swales, John. 2004. Research Genres: Explorations and Applications. Cambridge: Cambridge University Press.

Swales, John and Christine Feak. 2004. Academic Writing for Graduate Students: Essential Tasks and Skills. 2nd ed. Ann Arbor, MI: University of Michigan Press.

Swales, John and Hazem Najjar. 1987. The Writing of Research Article Introductions. Written Communication 4 (2): 175-191.

Tawalbeh, A2019. The Rhetoric of Accounts of Methodology in English and Arabic Educational Research Articles: A Contrastive Genre Analysis. PhD diss., University of Huddersfield.

Weissberg, Robert and Suzanne Buker. 1990. Writing up Research: Experimental Research Report Writing for Students of English. Englewood Cliffs, NJ: Prentice Hall Regents. 